\title{
BMD42-2910, a Novel Benzoxazole Derivative, Shows a Potent Anti-prion Activity and Prolongs the Mean Survival in an Animal Model of Prion Disease
}

\author{
Jae Wook Hyeon ${ }^{1}$, Ran Noh ${ }^{1}$, Jiwon Choi $^{2}$, Sol Moe Lee ${ }^{1}$, Yeong Seon Lee ${ }^{1}$, \\ Seong Soo A. $\mathrm{An}^{3}$, Kyoung Tai $\mathrm{No}^{2,4}$ and Jeongmin Lee ${ }^{5 *}$ \\ ${ }^{1}$ Division of Bacterial Disease Research, Center for Infectious Disease Research, Korea National Institute of Health, Centers \\ for Disease Control and Prevention, Cheongju 28160, ${ }^{2}$ Bioinformatics and Molecular Design Research Center, Yonsei \\ University, Seoul 03722, ${ }^{3}$ Gachon Bio Nano Research Institute, Gachon University, Seongnam 13120, ${ }^{4}$ Department of \\ Biotechnology, College of Life Science and Biotechnology, Yonsei University, Seoul 03722, ${ }^{5}$ Division of Research Planning, \\ Korea National Institute of Health, Centers for Disease Control and Prevention, Cheongju 28160, Korea
}

\begin{abstract}
Prion diseases are a group of neurodegenerative and fatal central nervous system disorders. The pathogenic mechanism involves the conversion of cellular prion protein $\left(\mathrm{PrP}^{\mathrm{C}}\right)$ to an altered scrapie isoform $\left(\mathrm{PrP}^{\mathrm{Sc}}\right)$, which accumulates in amyloid deposits in the brain. However, no therapeutic drugs have demonstrated efficacy in clinical trials. We previously reported that BMD42-29, a synthetic compound discovered in silico, is a novel anti-prion compound that inhibits the conversion of $\operatorname{PrP}^{\mathrm{C}}$ to protease $\mathrm{K}(\mathrm{PK})$-resistant $\operatorname{PrP}^{\mathrm{Sc}}$ fragments $\left(\operatorname{PrP}^{\mathrm{res}}\right)$. In the present study, 14 derivatives of BMD42-29 were obtained from BMD42-29 by modifying in the side chain by in silico feedback, with the aim to determine whether they improve anti-prion activity. These derivatives were assessed in a $\mathrm{PrP}^{\mathrm{Sc}}$-infected cell model and some derivatives were further tested using real timequaking induced conversion (RT-QuIC). Among them, BMD42-2910 showed high anti-prion activity at low concentrations in vitro and also no toxic effects in a mouse model. Interestingly, abundant $\mathrm{PrP}^{\text {res }}$ was reduced in brains of mice infected with prion strain when treated with BMD422910, and the mice survived longer than control mice and even that treated with BMD42-29. Finally, high binding affinity was predicted in the virtual binding sites (Asn159, Gln 160, Lys194, and Glu196) when PrP ${ }^{\mathrm{C}}$ was combined with BMD-42-2910. Our findings showed that BMD42-2910 sufficiently reduces $\mathrm{PrP}^{\text {res }}$ generation in vitro and in vivo and may be a promising novel anti-prion compound.
\end{abstract}

Key words: Transmissible spongiform encephalopathy, Prion protein, Anti-prion, Derivatives, In silico

\section{INTRODUCTION}

Prion diseases, or transmissible spongiform encephalopathies, are a group of neurodegenerative diseases, which share similar pathogenic mechanisms; the prion protein $(\mathrm{PrP})$ undergoes posttranslational modification and is converted from an endogenous

Received November 6, 2019, Revised February 4, 2020,

Accepted February 25, 2020

* To whom correspondence should be addressed.

TEL: 82-43-719-8024, FAX: 82-43-719-8489

e-mail: jeongminlee@korea.kr
$\left(\mathrm{PrP}^{\mathrm{C}}\right)$ to a pathogenic isoform $\left(\mathrm{PrP}^{\mathrm{Sc}}\right)$ [1-3]. This conversion leads to the changes of chemical and physical properties, including insolubility in non-denaturing detergents, partial resistance to protease digestion, and a high tendency to form aggregates and amyloid fibrils [4-6]. Prion diseases are associated with $\mathrm{PrP}^{\mathrm{Sc}}$ accumulation in the brain, specifically of PrP amyloid fibrils. Currently, the mechanisms underlying this conversion are incompletely defined $[7,8]$. The invariable lethality of prion diseases necessitates the identification of compounds that prevent misfolding of $\mathrm{PrP}^{\mathrm{C}}$, replication, or accumulation of $\operatorname{PrP}^{\text {Sc }}[9,10]$.

Current knowledge on prion diseases has revealed potential therapeutic strategies, including the prevention of the conversion
Copyright $\odot$ Experimental Neurobiology 2020. www.enjournal.org
This is an Open Access article distributed under the terms of the Creative Commons Attribution Non-Commercial License (http://creativecommons.org/licenses/by-nc/4.0) which permits unrestricted non-commercial use, distribution, and reproduction in any medium, provided the original work is properly cited. 
to PrP aggregates, induction of degradation of these aggregates, destabilization the $\operatorname{PrP}^{\mathrm{Sc}}$ structure, or interference with $\operatorname{PrP}^{\mathrm{C}} / \operatorname{Pr} \mathrm{P}^{\mathrm{Sc}}$ cellular uptake [11]. Therapeutic trials have been conducted using a wide variety of potential prion diseases treatments, and numerous compounds have been extensively investigated to demonstrate anti-prion activity in cell culture models [12-14]. However, no current treatment has sufficient activity to halt disease progression in infected animal models. The therapeutic use of these compounds is restricted by their intrinsic cytotoxicity and pharmacokinetic properties of drug delivery, including absorption and circulation, as well as by their limited ability to pass through the blood-brain barrier (BBB), resulting in failed efficacy in vivo $[15,16]$. Moreover, the few compounds that have been tested in humans at the post-symptomatic stage of the disease, including flupirtine [17], quinacrine [18], vidarabine [19], pentosan polysulfate [20], chlorpromazine $[21,22]$ and doxycycline [23], do not significantly alter the clinical course of the disease. Limitations may include oral administration, non-specific binding to $\operatorname{PrP}^{\mathrm{C}}$, high toxicity even at low doses, partial effects on clinical symptoms that do not extend to increased survival, and transient activity in the brain depending on the disease course [24].

We previously described the discovery of small anti-prion molecules obtained from a combined structure and ligand-based virtual screening system in silico. This approach allows the effective screening of anti-prion compounds that are structurally different from known active compounds, as it reduces both time and cost. Moreover, during docking into $\mathrm{PrP}^{\mathrm{C}}$ hotspot regions, blocking of conversion, stability, and crossing the BBB can be predicted. Various in vitro tests have demonstrated that BMD42-29 is particularly outstanding, as it blocks conversion or reduces the protease $\mathrm{K}$ (PK)-resistant $\operatorname{PrP}^{\mathrm{Sc}}$ fragments $\left(\operatorname{PrP}^{\text {res }}\right)$ [25]. $\operatorname{PrP}^{\mathrm{Sc}}$ s mean infectious PrP aggregates and are generated by conversion of endogenous $\operatorname{PrP}^{\mathrm{C}}$ in infected cells and mammals. $\operatorname{PrP}^{\text {res }}$ s mean PK-resistant and have pathological core forms of amino acids 90-231 of $\operatorname{PrP}^{\mathrm{Sc}}$, and also are generated from the in vitro conversion of recombinant PrP, like a real time-quaking induced conversion (RT-QuIC) assay. These aggregates can be detected by western blotting and inhibited by anti-PrP compounds [26]. Additionally, the structural mechanisms of BMD42-29 inhibition have been studied [27]. In the present study, we extended previous research by designing the derivatives of BMD42-29 using in silico feedback, specifically with chemical modifications based on docking pose of BMD42-29; the aim was to elucidate the improved anti-prion activity compared to that achieved by a previous procedure [25]. Here, we screened the anti-prion activities of the derivatives in a $\operatorname{PrP}^{\mathrm{Sc}}$-infected cell model and by using an RT-QuIC assay. Of them, the most effective derivatives were compared with BMD42-29 in a $\operatorname{PrP}^{\mathrm{Sc}}$-infected mouse model to identify their toxicities and anti-prion activities. And virtual binding sites were additionally selected. The findings have potential relevance to prion diseases treatment, thereby contributing to decreasing the lethality of prion diseases.

\section{MATERIALS AND METHODS}

\section{Compounds}

The derivatives having a core structure of BMD42-29 (Nphenylbenzo[d] oxazole-5-sulfonamide) were designed and docked into the 2D structure of $\operatorname{PrP}^{\mathrm{C}}$ using the ChemDraw Ultra as reported before [25]. As the final outcome, 14 derivatives with high binding energy were selected, named as BMD42-2901 to BMD42-2914, and their structures were optimized. BMD42-2901 to 2909 were synthesized in the Enamine (Monmouth Junction, NJ, USA), BMD42-2910 to 2912 were synthesized in the Akos Consulting \& Solutions GmbH (Steinen, Germany) and BMD422913 and BMD42-2914 were synthesized in the Interchem (Paramus, NJ, USA) and ChemDiv(San Diego, CA, USA), respectively. For in vivo study, BMD42-29 and BMD42-2910 were additionally synthesized in the 4Chem Laboratory (Gyeonggi-do, Republic of Korea). Their purity was determined by HPLC or proton NMR to be $>95 \%$. The chemical structures of 14 derivatives and BMD4229 were described in Fig. 1. Quinacrine dihydrochloride was purchased from Sigma-Aldrich (Saint Louis, MO, USA; Q3251). All tested compounds were dissolved in DMSO, diluted to produce a $50 \mathrm{mM}$ stock solution, and stored at $-20^{\circ} \mathrm{C}$ for in vitro and in vivo testing. The stock compounds were re-suspended in $0.03 \mathrm{~N} \mathrm{NaOH}$ in PBS just before use.

\section{Inhibition of PrP ${ }^{\text {res }}$ in scrapie-infected cells}

Prion-infected murine neuroblastoma ( $\mathrm{ScN} 2 \mathrm{a})$ cells, derived from the neuroblastoma-2a cell line of the American Type Culture Collection are stably infected with $\operatorname{PrP}^{\mathrm{Sc}}$ (Rocky Mountain Laboratory [RML] strain); the cells were generously provided by Dr. Ryu at Hanyang University in Republic of Korea. Cell culture was performed as described previously [25]. Briefly, cells were seeded in T- $25 \mathrm{~cm}^{2}$ flasks (TPP, Z707481) at $2 \times 10^{5}$ cells, and pre-incubated in DMEM (Gibco, Big Carbin, OK, USA) (12430) containing 10\% fetal bovine serum, 1\% penicillin-streptomycin (Gibco, 15140), and $2 \mathrm{mM} \mathrm{L}$-glutamine (Gibco, 25030) for $24 \mathrm{~h}$ under 5\% $\mathrm{CO}_{2}$ at $37^{\circ} \mathrm{C}$. The media were replaced with fresh media containing the test compounds. After incubation for 3 days, the media were again replaced with fresh media containing the test compounds, and cells were incubated for 3 days more. Finally, the cells were harvested after incubation with the compounds for 6 days. The stock solutions of 14 derivatives were diluted in DMEM to a final 


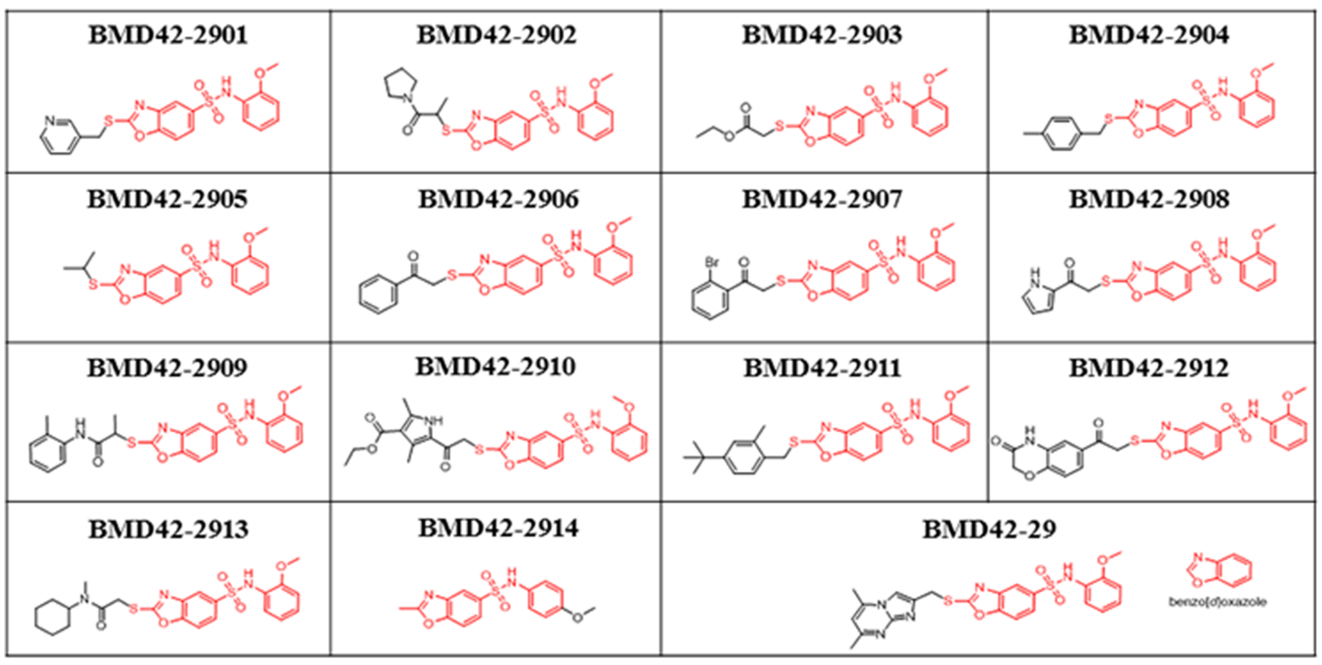

Fig. 1. Chemical structures of BMD42-29 and its derivatives. The red components of the derivatives are templates originated from BMD42-29, and the black components are modifiable. concentration of $20 \mu \mathrm{M}$. Control cell cultures were treated with DMSO only $(0.1 \% \mathrm{v} / \mathrm{v})$ and quinacrine $(1 \mu \mathrm{M})$ as activity controls. Secondary cell testing was dose-dependently performed at concentrations of $1.2,2.5,5$, and $10 \mu \mathrm{M}$. Each compound was tested in duplicate, in three independent experiments.

The cells were rinsed once in PBS and then incubated with $0.1 \%$ (vol/vol) trypsin-EDTA (Gibco, 25300) for $1 \mathrm{~min}$ at room temperature. The detached cells were centrifuged at $4000 \times \mathrm{g}$ for $10 \mathrm{~min}$ at $4{ }^{\circ} \mathrm{C}$ and rinsed once with PBS. Cells were lysed in ice-cold lysis buffer (10 mM EDTA, 10 mM Tris, pH 8.0, 100 mM NaCl, 0.5\% [wt/vol] Nonidet P-40, and 0.5\% [wt/vol] sodium deoxycholate), with two freeze-thaw cycles in liquid nitrogen, and then sonicated at an amplitude of $30 \%$. The total protein concentration of cell lysates was adjusted to $200 \mu \mathrm{g} / \mathrm{mL}$.

Cell lysates were digested with PK $(20 \mu \mathrm{g} / \mathrm{mL})$ (Merck, Kenilworth, NJ, USA) (70663) for $60 \mathrm{~min}$ at $37^{\circ} \mathrm{C}$. The reaction was stopped with $2 \mathrm{mM}$ Pefabloc (Roche, 11429876001), and the lysates were centrifuged for $90 \mathrm{~min}$ at $20,000 \times \mathrm{g}$ at $4{ }^{\circ} \mathrm{C}$. Pellets were resuspended in SDS sample buffer (125 mM Tris- $\mathrm{HCl}, \mathrm{pH} 6.8,5 \%$ [vol/vol] glycerol, 6 mM EDTA, 5\% [wt/vol] SDS, 0.04\% [vol/vol] bromophenol blue, and $12.5 \%$ [vol/vol] $\beta$-mercaptoethanol).

Protein mixtures were separated by SDS-polyacrylamide gel electrophoresis for $2 \mathrm{~h}$ at $150 \mathrm{~V}$, at $4{ }^{\circ} \mathrm{C}$, using $12 \%$ gels. Proteins were then transferred to a PVDF membrane using the i-Blot system (Invitrogen, Carlsbad, CA, USA) for $7 \mathrm{~min}$. The membrane was blocked for $1 \mathrm{~h}$ at room temperature in $5 \%$ (wt/vol) skim milk in PBS containing $0.1 \%$ ( $\mathrm{vol} / \mathrm{vol}$ ) Tween 20 (PBS-T), and then incubated overnight at $4{ }^{\circ} \mathrm{C}$ with the monoclonal PrP antibody 6H4 (1:2500; Prionics, Zurich, Switzerland; PRN-01-011), diluted in $10 \%$ (vol/vol) blocking buffer. After washing with PBS-T, the membrane was incubated for $1 \mathrm{~h}$ at room temperature with HRPconjugated anti-mouse IgG (1:5,000; DAKO, Santa Clara, CA,
USA; P0260). The signals were visualized using ECL (EBP-1073; Elpis Biotech, Daejeon, Republic of Korea), and the protein bands were scanned using Image Scanner III (GE, Munich, Germany). The relative band densities are shown as the volume intensity/ $\mathrm{mm}^{2}$, relative to the $\beta$-actin (1:5000; Cell Signaling technology, Beverly, MA, USA; 4970) band density.

\section{Total PrP measurement}

Total PrP in lysates of cells treated with desired compounds was measured using the ELISA kit for PRION (PRNP; Cloud-Clone Corp., Katy, Texas, USA) according to the manufacturer's instructions. The absorbance at $450 \mathrm{~nm}$ was measured using a plate reader (VICTOR3, PerkinElmer, MA, USA). All samples were analyzed in triplicate.

\section{Inhibition of PrP ${ }^{\text {res }}$ in RT-QuIC}

Human recombinant PrP (rPrP, residues 23-231; accession no. K02234) was produced, and the RT-QuIC reaction was performed as described in our previous report, as a modified method of Wilham et al. and Cramm et al. [28-30]. Briefly, Escherichia coli transfected with vector with human PrP sequence was grown in Luria broth medium with kanamycin and chloramphenicol. Protein was expressed by Overnight Express Autoinduction system (Novagen, Darmstadt, Germany; 71300). The rPrP was purified from inclusion bodies using Ni-NTA Superflow resin (Qiagen, Hilden, Germany; 30450). The protein was refolded under gradient condition, eluted with $10 \mathrm{mM}$ phosphate buffer ( $\mathrm{pH}$ 5.8). Protein purity was measured by SDS-PAGE, mass spectrometry. The final composition of the reaction buffer was as follows: $162 \mathrm{mM}$ phosphate buffer (pH 6.9), 170 mM NaCl, 1 mM EDTA, $10 \mu \mathrm{M}$ Thioflavin $\mathrm{T}$ (ThT), and $0.1 \mathrm{mg}$ rPrP. Ninety-six microliters of buffer were dispensed into each well of a clear-bottomed black 96-well micro- 
plate (Nunc, NY, USA; 265301).

Two microliters of diluted sporadic Creutzfeldt Jacob disease (sCJD) brain homogenate from the National Institute for Biological Standards and Control (NIBSC; reference code NHBX0/0001) were seeded into each well. Two microliters of each compound (BMD42-2908, 2909, 2910, and 2914; 1.2, 2.5, 5, 10, and $20 \mu \mathrm{M}$ ) and DMSO were added to designed wells. Compounds were solubilized in DMSO. The plate was sealed and incubated for $72 \mathrm{~h}$ at $44^{\circ} \mathrm{C}$, with intermittent shaking using a BMG Labtech Optima Fluostar plate reader. Each reaction was performed in quadruplicate. A positive response was indicated if the mean of the two highest readings at $72 \mathrm{~h}$ was greater than two-fold, compared to the negative control. In a previous study, to exclude the possibility that compounds were affecting the ThT fluorescence dye rather than substrate rPrP or PrP amyloid, RT-QuIC products were collected from wells after the last reaction, and $\operatorname{PrP}^{\text {res }}$ was detected using western blotting as mentioned above. Additionally, a dyeindependent conversion assay which is called Multimer Detection System (MDS) was performed to further confirm the nature of ThT. As a result, ThT-compound interference is not observed in optical (data not shown). This result was consistent with that of our previous experiment [30].

\section{Inhibition of $\operatorname{PrP}^{\text {res }}$ in mice}

In vivo toxicity tests were conducted in 6-weeks-old male and female wild-type mice (Institute of Cancer Research, London, UK). The mice were assigned to fourteen groups ( $n=5 /$ group). Three male and three female groups received each 4, 20, and $100 \mathrm{mg} / \mathrm{kg} / \mathrm{d}$ of BMD42-29. Also, three male and three female groups received each 4, 20, and $100 \mathrm{mg} / \mathrm{kg} / \mathrm{d}$ of BMD42-2910. One male and one female group received each DMSO with $0.03 \mathrm{~N} \mathrm{NaOH}$ in PBS as a control. The compounds were daily administered intraperitoneally using a 1-mL syringe and a 26-gauge, 1.27 - to $2.54-\mathrm{cm}(1 / 2$ to 1 inch) needle with a short bevel for 7 days. The injection was made in the lateral aspect of the lower left quadrant $[31,32]$. The volume injected into each mouse was $10 \mathrm{~mL} / \mathrm{kg}$. During and after daily compound administration, mice were closely observed for side effects by monitoring body weight and behavioral changes, such as drinking and eating patterns $[33,34]$. After 7 days, the following parameters were tested; clinical signs, body weights, food consumption, organ weights, hematological parameters, and clinical chemistry. The hematological parameters included the total erythrocyte count, hemoglobin, hematocrit, mean corpuscular volume, mean corpuscular hemoglobin $(\mathrm{MCH}), \mathrm{MCH}$ concentration, platelet count, and total leukocyte count. The clinical chemistry included assays for alanine aminotransferase, aspartate aminotransferase, alkaline phosphatase, glucose, blood urea nitrogen, creatinine, total cholesterol, triglycerides, total protein, albumin, and the $\mathrm{A} / \mathrm{G}$ ratio.

For in vivo infectivity tests, 8-weeks-old female wild-type C57BL/6 mice were assigned to five infected groups ( $\mathrm{n}=50 / \mathrm{com}$ pound group, $n=15 / \mathrm{DMSO}$ group) and one uninfected control group ( $n=10 /$ group). The five infected groups were inoculated intracerebrally (i.c.) with $20 \mu \mathrm{L}$ of $1 \%$ mouse-adapted scrapie (ME7) brain homogenate. At 30 days post-infection (DPI), the compounds and DMSO were weekly administered intraperitoneally until 200 DPI. Two infected groups received each 5 and 20 $\mathrm{mg} / \mathrm{kg} / \mathrm{w}$ of BMD42-29. The other two infected groups received each 5 and $20 \mathrm{mg} / \mathrm{kg} / \mathrm{w}$ of BMD42-2910. The remaining one infected group and the one uninfected group received DMSO with $0.03 \mathrm{~N} \mathrm{NaOH}$ in PBS. Health status was inspected daily, and body weights were recorded weekly over a period of 200 days. Seventeen to nineteen mice were euthanized at both designed 100 and 170 DPI for detection of $\operatorname{PrP}^{\text {res }}$. For survival test, eight to ten mice were euthanized after the onset of prion diseases-associated clinical symptoms (abnormal tail tonus, hindlimb paralysis, or weight loss) per group, and the same number of uninfected mice were treated with DMSO and observed parallelly [35]. Actually, one to three mice died for unknown reasons per group. Experimental design for both in vivo toxicity and infectivity were summarized in Table 1. Brains and spleens of the mice euthanized at 100 and 170 DPI were removed, weighed, homogenized in buffer (PBS; pH 7.4) containing $1 \mathrm{mM}$ EDTA, $5 \mathrm{M} \mathrm{NaCl}$, Triton X-100, and protease inhibitor, using a Precellys tissue homogenizer with glass beads to make $1 \%$ homogenate, and then used for western blotting. A total of $300 \mu \mathrm{L}$ of plasma was prepared from $700 \mu \mathrm{L}$ of whole blood, which was collected from the heart. From this sample, $30 \mu \mathrm{L}$ of plasma mixed with $10 \mu \mathrm{L}$ of sample buffer was used for western blotting. Mice that died from causes other than prion diseases were excluded from the data set [36]. The protein bands were scanned using Image Scanner III (GE). Scatter plots of individual data were generated using the ggplot 2 software package with R software package (version 3.4.3).

\section{Survival durations and hazardous factor analysis}

Survival durations were analyzed by Kaplan-Meier survival analysis, and hazardous factors were then generated using MedCalc Statistical Software version 17.6 (MedCalc Software bvba, Ostend, Belgium; http://www.medcalc.org; 2017) [37]. Significance was indicated by $\mathrm{p}<0.05$.

\section{Molecular docking}

Molecular docking calculations were performed using the CDOCKER program to identify binding mode of novel anti- 
Table 1. Experimental design for in vivo studies

\begin{tabular}{|c|c|c|c|c|c|c|c|}
\hline \multirow{2}{*}{ Toxicity (n) } & \multicolumn{3}{|c|}{ BMD42-29 } & \multicolumn{3}{|c|}{ BMD42-2910 } & \multirow{2}{*}{ DMSO } \\
\hline & $4 \mathrm{mg} / \mathrm{kg}$ & $20 \mathrm{mg} / \mathrm{kg}$ & $100 \mathrm{mg} / \mathrm{kg}$ & $4 \mathrm{mg} / \mathrm{kg}$ & $20 \mathrm{mg} / \mathrm{kg}$ & $100 \mathrm{mg} / \mathrm{kg}$ & \\
\hline Male & 5 & 5 & 5 & 5 & 5 & 5 & 5 \\
\hline Female & 5 & 5 & 5 & 5 & 5 & 5 & 5 \\
\hline \multirow{3}{*}{ Infectivity (n) } & \multicolumn{5}{|c|}{ Infected with $\operatorname{PrP}^{\mathrm{Sc}}$} & \multicolumn{2}{|c|}{ Uninfected } \\
\hline & \multicolumn{2}{|c|}{ BMD42-29 } & \multicolumn{2}{|c|}{ BMD42-2910 } & DM & \multirow{2}{*}{\multicolumn{2}{|c|}{ DMSO }} \\
\hline & $5 \mathrm{mg} / \mathrm{kg}$ & $20 \mathrm{mg} / \mathrm{kg}$ & $5 \mathrm{mg} / \mathrm{kg}$ & $20 \mathrm{mg} / \mathrm{kg}$ & DIVISU & & \\
\hline Female (Total) & 50 & 50 & 50 & 50 & 15 & \multicolumn{2}{|c|}{10} \\
\hline For 100 DPI & 20 & 20 & 20 & 20 & 5 & & \\
\hline For 170 DPI & 20 & 20 & 20 & 20 & 5 & & \\
\hline For survival & 10 & 10 & 10 & 10 & 5 & 10 & \\
\hline
\end{tabular}

prion compound, which uses a CHARMm forcefield and gridbased molecular dynamics docking method. To determine the binding pose of compounds to the hotspot binding site of $\operatorname{PrP}^{\mathrm{C}}$, the NMR structure of $\operatorname{PrP}^{\mathrm{C}}$ (1AG2) was retrieved from the Protein Data Bank. The hotspot regions of $\operatorname{PrP}^{\mathrm{C}}$ with key residues (Asn159, Gln160, Lys194, and Glu196) was used to define the binding site of $\mathrm{PrP}^{\mathrm{C}}$. The best docking pose for each compound was selected based on the best scoring conformations from LigScore2, binding patterns, and visual inspection. The predicted structures of $\operatorname{PrP}^{\mathrm{C}}$ compound complexes were visualized using the PyMOL program.

\section{Statistical analyses}

Each experiment was repeated three times. One-way analysis of variance with Tukey-Kramer post hoc tests was conducted using Microsoft Excel and SAS (version 9.3). Differences were considered statistically significant when $\mathrm{p}<0.05$.

\section{RESULTS}

\section{Derivatives}

To investigate the interaction pattern of BMD42-29 on the hotspot regions of $\mathrm{PrP}^{\mathrm{C}}$ with key residues, we conducted molecular docking experiments. N-phenylbenzo[d] oxazole-5-sulfonamide group of BMD42-29 interacted with Asn 159 and Gln160 of $\mathrm{PrP}^{\mathrm{C}}$ and docked into a cavity surrounded by Pro 158, Asn 159 and Gln160, which indicated that benzene sulfonamide group likely contributes to the tight binding with $\mathrm{PrP}^{\mathrm{C}}$. Consequently, we decided to use N-phenylbenzo[d] oxazole-5-sulfonamide group of BMD42-29 as the starting point for further compound modifications. From the interaction patterns of the hotspot region, we expected that the substitution of a imidazo $[1,2-\alpha]$ pyrimidine group would allow compounds with other substituents at this position to bind the $\operatorname{PrP}^{\mathrm{C}}$ and increase the binding specificity. In order to identify BMD42-29 derivatives of the hotspot region binding interaction with core scaffolds, we performed substructure search screening from integrated database. Finally, the 14 derivatives were identified by docking simulations and evaluated for experimental validation.

\section{Anti-prion activity of derivatives in a cell model}

Inhibition of $\mathrm{PrP}^{\mathrm{res}}$ amplification was observed in $\mathrm{ScN} 2 \mathrm{a}$ cells treated with 14 derivatives (Fig. 2). As previously reported, no cytotoxicity was observed in compounds derived in silico below 20 $\mu \mathrm{M}$, which was consistent with the derivatives used in the present study (data not shown) [25]. Therefore, $20 \mu \mathrm{M}$ was regarded as an optimal dose and was administered to cells (Fig. 2A). Like that treated with DMSO, BMD42-2901, BMD42-2905, and BMD422913 treatment did not inhibit $\operatorname{PrP}^{\text {res }}$ amplification in cells. We observed a partial reduction of $\mathrm{PrP}^{\text {res }}$ levels $<50 \%$ in BMD422902, BMD42-2903, and BMD42-2907, whereas BMD42-2904, BMD42-2906, BMD42-2911, and BMD42-2912 reduced a partial of $\mathrm{PrP}^{\text {res }}$ levels $>50 \%$. The BMD42-2908, BMD42-2909, BMD422910, and BMD42-2914 reduced PrP $\mathrm{P}^{\text {res }}$ levels by $>90 \%$, similarly to what is observed with quinacrine. To identify dose-dependent activities, four effective derivatives (BMD42-2908, BMD42-2909, BMD42-2910, and BMD42-2914) were serially diluted to 1.2, 2.5, 5, and $10 \mu \mathrm{M}$ and applied to cells (Fig. 2B). Dose-response inhibition was identified by all four effective derivatives.

The four effective derivatives reduced $\operatorname{PrP}^{\text {res }}$ levels even at $1.2 \mu \mathrm{M}$. The $\mathrm{IC}_{50}$ values were $1.8 \mu \mathrm{M}$ for BMD42-2908, $5 \mu \mathrm{M}$ for BMD422909, <1.2 $\mu \mathrm{M}$ for BMD42-2910, and 2.1 $\mu \mathrm{M}$ for BMD42-2914. More than $90 \%$ inhibition was observed at 5 and $10 \mu \mathrm{M}$ BMD422910 and at $10 \mu \mathrm{M}$ BMD42-2914.Given doses of the derivatives with similar activity, BMD42-2910 was the most effective derivative compound. Semi-quantitative intensities for Fig. $2 \mathrm{~A}$ and $2 \mathrm{~B}$ bands are provided in Fig. 2C and 2D, respectively. The expression 
A

$\mathrm{B}$

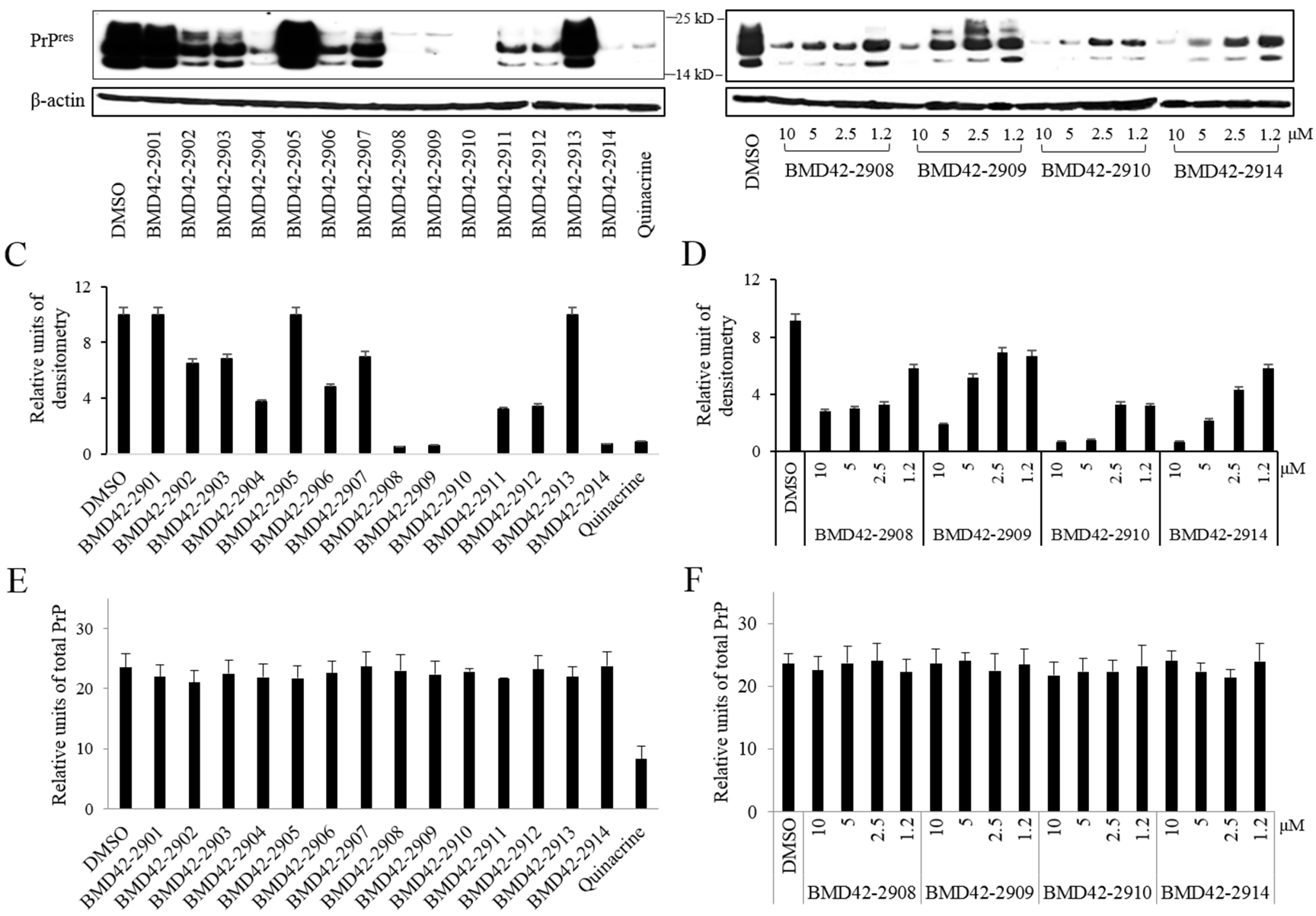

Fig. 2. Inhibition of $\operatorname{PrP}^{\text {res }}$ amplification in ScN2a cells treated with 14 derivatives of BMD42-29. Effects of 14 derivatives (20 $\left.\mu \mathrm{M}\right)(\mathrm{A})$, dose-dependent four effective derivatives (1.2 10 $\mu \mathrm{M})(\mathrm{B})$ on inhibition of $\mathrm{PrP}^{\mathrm{res}}$ amplification in ScN2a cells were assessed by western blotting. Relative units of densitometry for (A) and (B) indicate the volume intensity $/ \mathrm{mm}^{2}$, relative to $\beta$-actin signal in (C) and (D), respectively. Total PrP was measured in ScN2a cells treated with 14 derivatives $(20 \mu \mathrm{M})(\mathrm{E})$ and dose-dependent four effective derivatives $(1.2 \sim 10 \mu \mathrm{M})(\mathrm{F})$. Controls were treated with DMSO and quinacrine. Each value represents the mean \pm standard deviation; $\mathrm{p}<0.05$. Three independent experiments were performed in duplicate, and representative immunoblots are shown. Molecular mass markers are indicated to the between two blots.

of total PrP was constant in conditions of various compounds and doses, except for quinacrine (Fig. 2E and 2F). This suggested that BMD42-2910 as well as other derivatives only affected $\operatorname{PrP}^{\text {res }}$ at low concentrations without change of total PrP.

\section{Anti-prion activity of derivatives in RT-QuIC}

Blocking activity of $\operatorname{PrP}^{\mathrm{C}}$ conversion was observed by RT-QuIC using BMD42-2908, BMD42-2909, BMD42-2910, and BMD422914 with the same doses (Fig. 3). Increased and decreased fluorescence indicate that $\operatorname{PrP}$ aggregation is generated and blocked, respectively. The fluorescence was increased in DMSO controls of all experiments at $5 \sim 11 \mathrm{~h}$, indicating that $\mathrm{PrP}^{\mathrm{C}}$ conversion was rapidly generated without any disruptions. In case of BMD42-2908, fluorescence is not elevated at $20 \mu \mathrm{M}$ until $62 \mathrm{~h}$, whereas it was elevated in most concentrations at 18 22 h, indicating that there was no blocking activity at most doses of BMD42-2908. Also, the higher the dose, the later the amplification began, indicating that showed the partial blocking activity dose-dependently (Fig. 3A). In case of BMD42-2909, fluorescence was increased at 8 18 h in all doses similar to that of the DMSO control, indicating that $\operatorname{PrP}^{\mathrm{C}}$ conversion was not blocked by BMD42-2909 and even it did not show the partial blocking activity (Fig. 3B).

In case of BMD42-2910, the baseline level of fluorescence was maintained at 5,10 , and $20 \mu \mathrm{M}$ until the last reading (72 h), except that the fluorescence was increased at around $62 \mathrm{~h}$ in wells treated with 1.2 and $2.5 \mu \mathrm{M}$ (Fig. 3C). This result suggested that $\operatorname{PrP}^{\mathrm{C}}$ conversion was completely blocked until the last reaction, and also the concentration required for blocking activity was relatively low in 
A

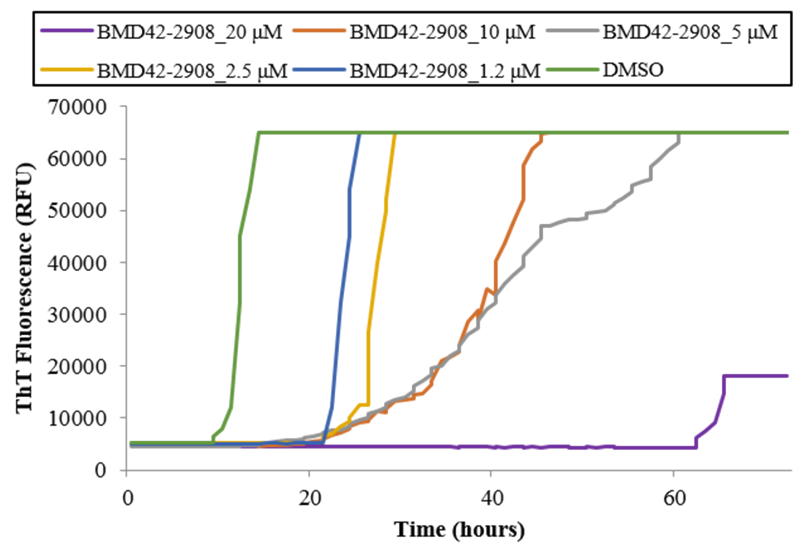

C

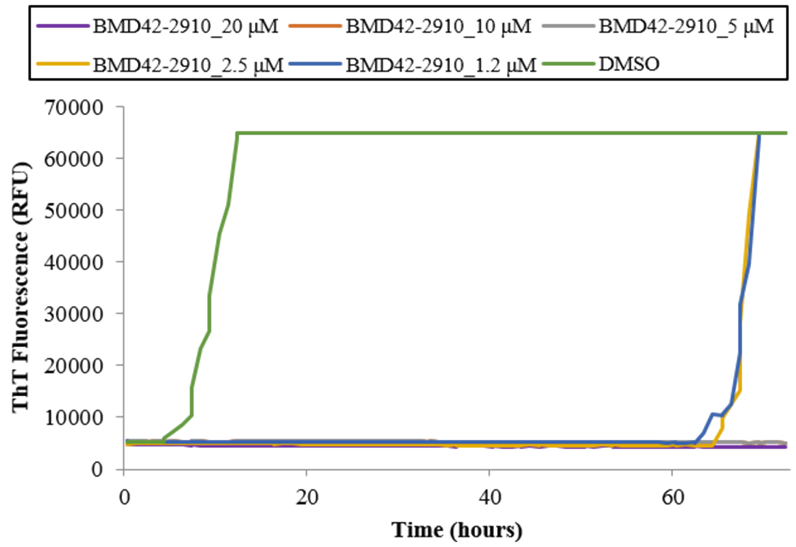

B

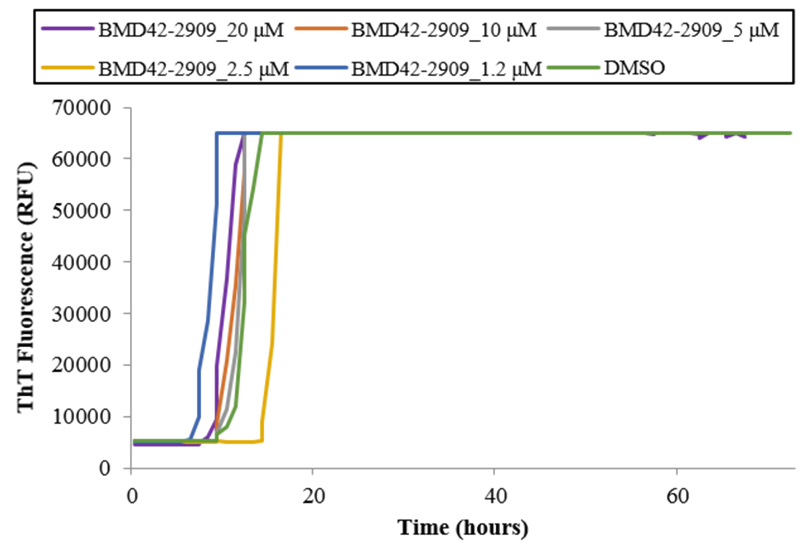

$\mathrm{D}$

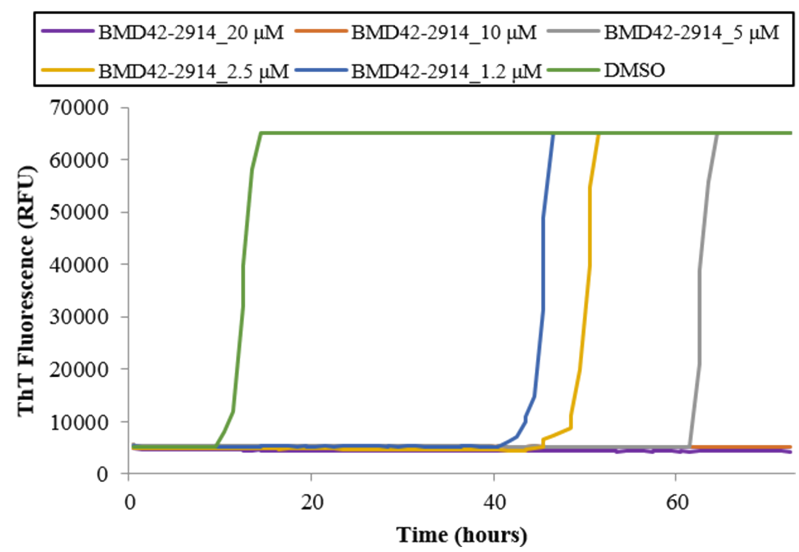

Fig. 3. Blocking activity of four derivatives against in vitro conversion of $\operatorname{PrP}^{\mathrm{C}}$ by RT-QuIC. The conversion of $\operatorname{PrP}^{\mathrm{C}}$ was observed in the wells treated with (A) BMD42-2908, (B) BMD42-2909, (C) BMD42-2910, and (D) BMD42-2914 at concentrations of 1.2, 2.5, 5, 10, and 20 $\mu$ M. RT-QuIC reaction buffer was mixed with the brain homogenate of sCJD patient and each compound, and then it was incubated for $72 \mathrm{~h}$ at $44^{\circ} \mathrm{C}$, with intermittent shaking. Each condition was performed in quadruplicate. The mean ThT fluorescence values were plotted against time.

BMD42-2910. In case of BMD42-2914, the baseline fluorescence was maintained at 10 and $20 \mu \mathrm{M}$ until the last reading (72 h), except that the fluorescence was partially elevated at 1.2, 2.5, and 5 $\mu \mathrm{M}$ (Fig. 3D). Given that the threshold concentration of BMD422910 showing completely blocking activity was $5 \mu \mathrm{M}$ and the partial blocking activity was also much more effective than that of other derivatives, BMD42-2910 was the most effective anti-prion activity.

\section{Toxicological assessments of BMD42-29 and BMD42-2910 in uninfected mice}

Based on cell and RT-QuIC assays, BMD42-2910 was selected for further in vivo studies among the derivatives. Therefore, BMD42-29 as a main body and BMD42-2910 were administered intraperitoneally to normal ICR mice to conduct toxicological tests. We did not observe any significant differences in daily obser- vation such as clinical signs, body weights, and food consumption, organ weight, hematological parameters and clinical chemistry in mice treated with BMD42-29 and BMD42-2910 for a week, even though weights of liver and spleen and the albumin/globulin (A/ $\mathrm{G})$ ratios were slightly changed than in control in some cases (data not shown). Therefore, we concluded that those compounds were not toxic in vivo at concentrations $\leq 100 \mathrm{mg} / \mathrm{kg} / \mathrm{d}$.

\section{Anti-prion activity of BMD42-29 and BMD42-2910 in PrP $P_{\text {- }}^{S c}$ infected mice}

Considering both the optimal inhibitory concentration of $20 \mu \mathrm{M}$ $(10 \mathrm{mg} / \mathrm{kg}$ ) in cells and RT-QuIC and the maximum of $100 \mathrm{mg} / \mathrm{kg}$ in in vivo toxicological tests, the predicted optimal and non-toxic doses were 5 and $20 \mathrm{mg} / \mathrm{kg}$ and used to assess anti-prion activity in vivo. The mice were infected intracerebrally at first and administered intraperitoneally from 30 DPI once a week. Fig. 4A showed 


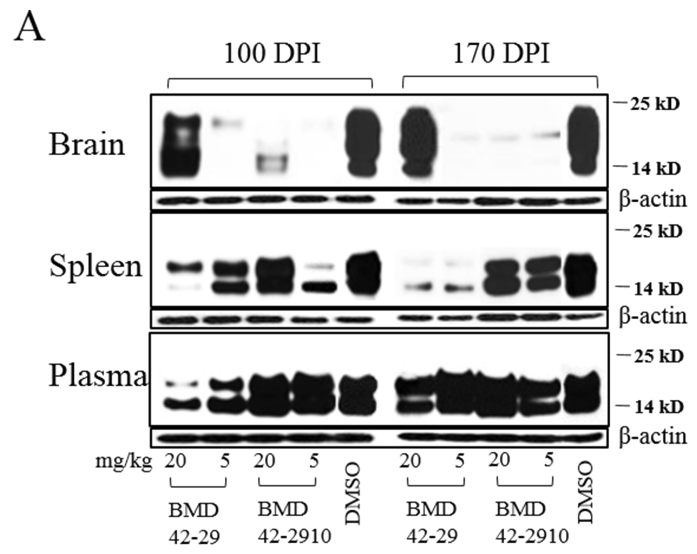

$\mathrm{C}$

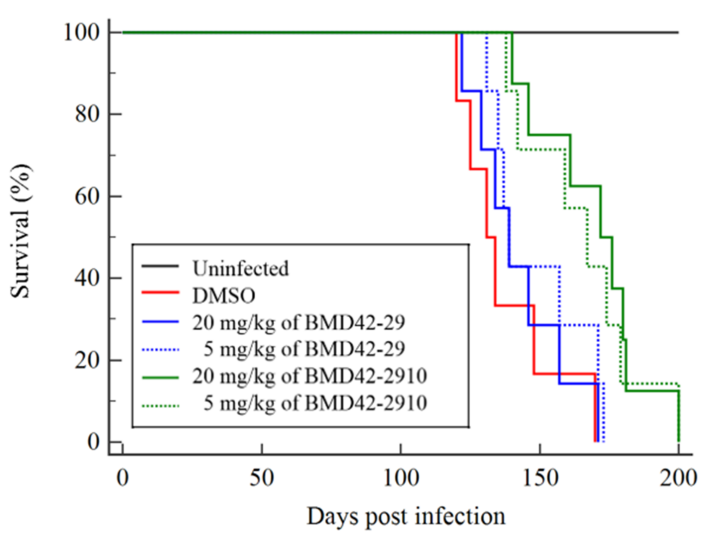

$\mathrm{B}$

100 DPI
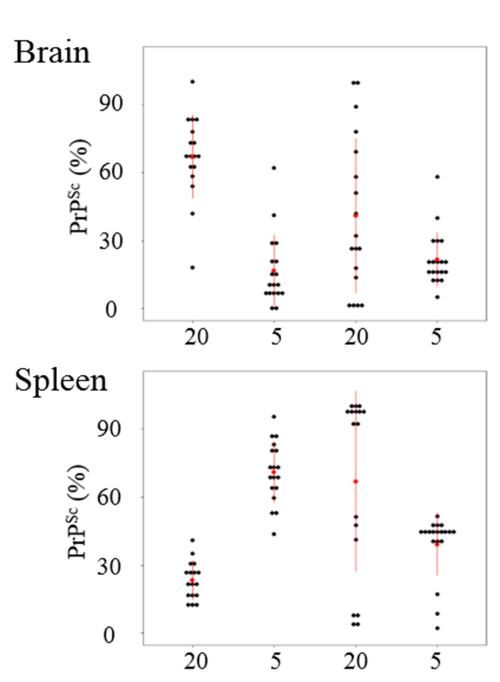
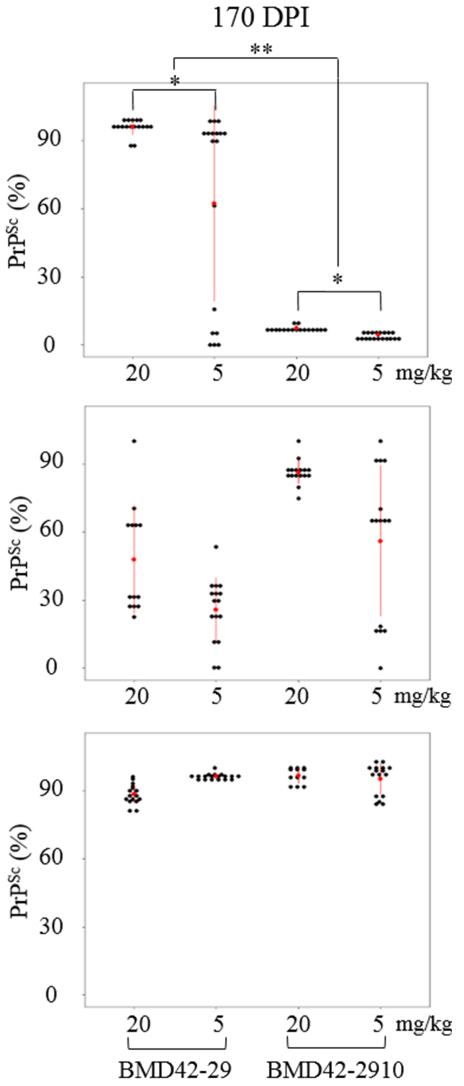

Fig. 4. Inhibition of PrP ${ }^{\text {res }}$ amplification in ME7-infected mice treated with BMD42-29 or BMD42-2910. Effects of BMD42-29 and BMD42-2910 on $\mathrm{PrP}^{\mathrm{res}}$ amplification in ME7-infected mice were analyzed. The infected mice were treated with $5 \mathrm{and} 20 \mathrm{mg} / \mathrm{kg}$ of the compounds and DMSO. At 100 and 170 DPI, seventeen to nineteen mice per a group were euthanized, and their brain, spleen, and plasma were immunoblotted after PK treatment. Representative blots are shown per a group, with molecular mass markers indicated to the right of the blots (A). Individual PrP ${ }^{\text {res }}$ levels were shown by scatter plots (B). Each spot corresponds to band intensity/DMSO band intensity $\times 100 .{ }^{*} \mathrm{p}<0.05 .{ }^{* *} \mathrm{p}<0.001$. Survival durations of the eight to ten mice per a group infected with ME7 and treated with 20 (line) and 5 (dotted line) mg/kg per week of BMD42-29 (blue), BMD42-2910 (green) or DMSO (red line), and uninfected mice treated with DMSO (black line) are shown by Kaplan-Meier curves (C).

representative immunoblots for $\operatorname{PrP}^{\text {res }}$ obtained from brain, spleen, and plasma samples from $\mathrm{PrP}^{\mathrm{Sc}}$-infected mice treated with BMD42-29 or BMD42-2910 at concentrations of 5 and $20 \mathrm{mg} / \mathrm{kg}$. Compared to DMSO-treated mice, $\operatorname{PrP}^{\text {res }}$ was reduced in brains of mice treated with 5 and $20 \mathrm{mg} / \mathrm{kg}$ of BMD42-2910 and $5 \mathrm{mg} /$ $\mathrm{kg}$ of BMD42-29. No anti-prion activity was observed in brains treated with $20 \mathrm{mg} / \mathrm{kg}$ BMD42-29. Anti-prion activity was much more effective at 170 than 100 DPI in brains of mice treated with BMD42-2910. PrP ${ }^{\text {res }}$ in spleen was not reduced by BMD42-2910; in contrast, BMD42-29 showed anti-prion activity in spleen at 170 DPI. However, $\operatorname{PrP}^{\text {res }}$ in plasma was not affected.

Each individual immunoblot data were displayed as scatter plots (Fig. 4B). There were individual differences in all brains at 100 DPI. However, most data were distributed without individual differences in the brains at $170 \mathrm{DPI}$, except for $5 \mathrm{mg} / \mathrm{kg}$ of BMD4229 at 170 DPI. Although $\mathrm{PrP}^{\text {res }}$ of brain was reduced in $5 \mathrm{mg} / \mathrm{kg}$
BMD42-29, $5 \mathrm{mg} / \mathrm{kg}$ BMD42-2910, and $20 \mathrm{mg} / \mathrm{kg}$ BMD42-2910 at 100 DPI as shown in Fig. 4A, the individual differences may not support the conclusion that they represented anti-prion activity. Therefore, BMD42-29 and BMD42-2910 partially reduced $\operatorname{PrP}^{\text {res }}$ of brain at 100 DPI. By contrast, PrP ${ }^{\text {res }}$ of brain was almost completely reduced in 5 and $20 \mathrm{mg} / \mathrm{kg}$ BMD42-2910 at 170 DPI. It was consistent with their individual data without the differences. Hence, the findings in brains that 5 and $20 \mathrm{mg} / \mathrm{kg}$ of BMD42-2910 showed anti-prion activity at 170 DPI were reliable. As was the case in brains, the individual differences of $\operatorname{PrP}^{\text {res }}$ of pleen was hard to conclude that they represented anti-prion activity. It was consistently ineffective in plasma. But in part, the anti-prion activity was higher in spleen than in plasma, considering degree of variation between individuals.

Furthermore, survival rates were measured in $\operatorname{PrP}^{\mathrm{Sc}}$-infected mice treated with BMD42-29 and BMD42-2910. Kaplan-Meier 
survival analysis demonstrated that mice treated with 5 and 20 $\mathrm{mg} / \mathrm{kg}$ BMD42-2910 survived longer than mice treated with 5 and $20 \mathrm{mg} / \mathrm{kg}$ BMD42-29 or DMSO (Fig. 4C). Survival durations were increased by approximately 7 and 30 days in mice treated with BMD42-29 and BMD42-2910, respectively. Mean hazard ratios with 95\% confidence intervals indicated that it was reduced in treatment of BMD42-29 and BMD42-2910, as compared with that of DMSO (Table 2).

\section{The docking conformation of BMD42-29 and BMD42-2910 to $\operatorname{PrP}^{C}$ at specific amino acids}

The predicted binding modes of BMD42-29, BMD42-2910, and BMD42-2904 on PrP $^{\mathrm{C}}$ hotspot binding site were shown in Fig. 5. We identified that the docked pose of BMD42-2910 has a similar conformation to that of $\operatorname{PrP}^{\mathrm{C}}$-BMD42-29 complexes. After applying the LigScore 2 scoring functions for filtering, the best poses were selected based on exhibiting good interactions with hotspot residues (Asn159, Gln160, Lys194, and Glu196). The BMD42-29 and BMD42-2910 interacted strongly with Asn159, Gln160 and Lys 194 or Glu196 by forming hydrogen bonding interactions, as well as intermolecular $\pi$-stacking interactions through its benzoxazole ring (Fig. 5A and 4B). However, BMD42-2904 failed to forms hydrogen bonds with Lys194 or Glu196 because of its relatively

Table 2. Mean hazard ratios with 95\% confidence intervals generated from the Kaplan-Meier curves

\begin{tabular}{rccc}
\hline \multirow{2}{*}{ Doses } & \multicolumn{2}{c}{ Compounds } & \multirow{2}{*}{ DMSO } \\
\cline { 2 - 3 } & BMD42-29 & BMD42-2910 & \\
\hline $5 \mathrm{mg} / \mathrm{kg}$ & $1.39(0.39 \sim 5.11)$ & $0.59(0.19 \sim 1.89)$ & $2.67(0.53 \sim 13.61)$ \\
$20 \mathrm{mg} / \mathrm{kg}$ & $1.94(4.49 \sim 7.95)$ & $0.46(0.15 \sim 1.47)$ & \\
\hline
\end{tabular}
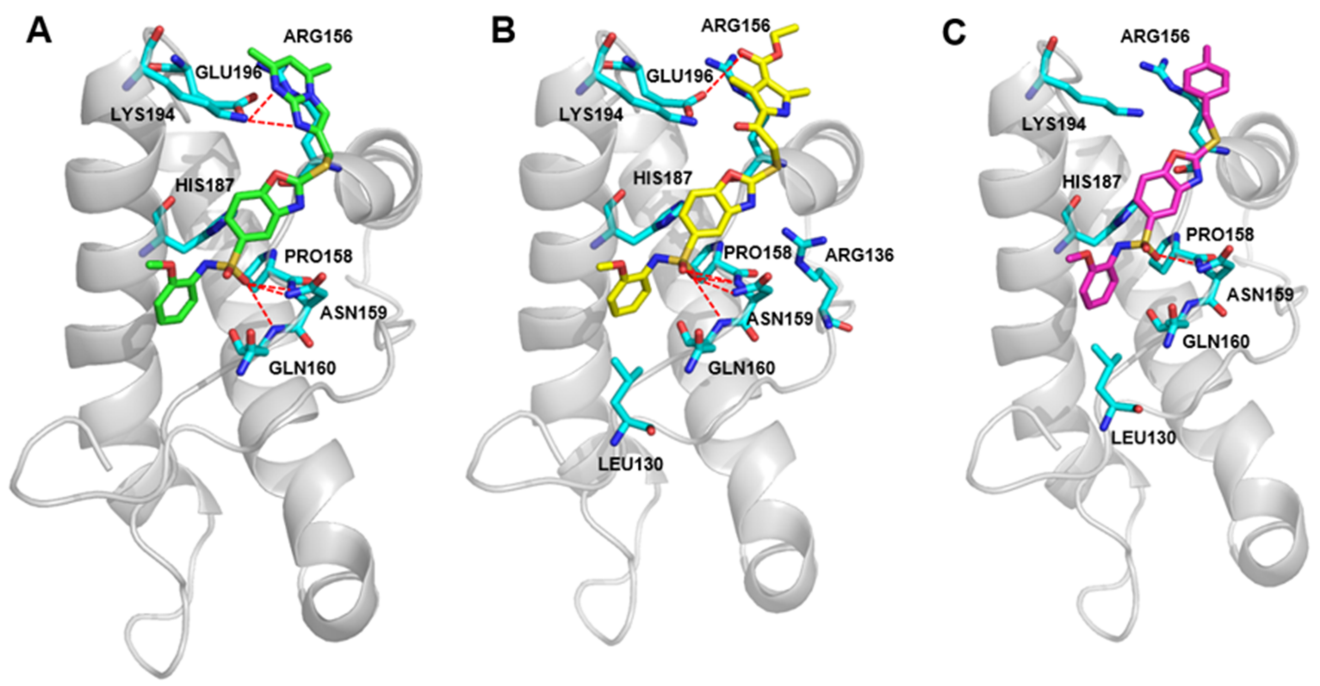

Fig. 5. Molecular docking studies of the compounds with cellular prion protein $\left(\mathrm{PrP}^{\mathrm{C}}\right)$. Key residues (cyan sticks) involved in the ligand-protein interactions are shown as stick model and $\mathrm{H}$-bonds are indicated by red dashed lines. The protein surface is colored in light gray and BMD42-29 (A), BMD42-2910 (B), and BMD42-2904 (C) are shown as green, yellow, and magenta sticks, respectively. Images were drawn with PyMol (Delano Scientific LLC, San Carlos, CA, USA). 
ity, which suggests that BMD42-35 acts by either stabilizing or eliminating $\operatorname{PrP}^{\mathrm{C}}$ and may control $\operatorname{PrP}^{\mathrm{C}}$ via non-specific mechanisms. Hence, we found the derivatives of BMD42-29 based on its remarkable inhibition for $\mathrm{PrP}^{\text {res }}$ amplification and strong binding affinity, with the aim to determine more effective compounds via in vivo testing.

Infectious forms of animal prions can be propagated in cell culture, notably in $\mathrm{ScN} 2$ a cell lines [42, 43]. Various immunological methods are available to measure prion load in these cell lines, and therefore provide a valuable means of evaluating the anti-prion activity of potential compounds. We performed RT-QuIC by ThT fluorescence, as well as western blotting of cell lysates using a PrP antibody. RT-QuIC is a recent innovation that allows real-time detection and monitoring of $\mathrm{rPrP}$ conversion to amyloid form [28]. RT-QuIC has been successfully used to detect small amounts of $\operatorname{PrP}^{\mathrm{Sc}}$ in brain tissue, cerebrospinal fluid, blood, saliva, and nasal fluid from human, cervid, ovine, bovine, and rodent species. $\operatorname{PrP}$ amyloid resulting from the conversion of $\mathrm{rPrP}$ to its aggregated form is indicated by increased ThT fluorescence, which directly indicates beta-sheet structure formation in protein aggregates [44]. Inhibitory effects of blocking $\operatorname{PrP}^{\mathrm{C}}$ conversion were confirmed both in our cell model and by RT-QuIC in vitro. Anti-prion effects of BMD42-2910 and BMD42-2914 were also observed in cells, but differed from those observed by RT-QuIC, indicating that BMD42-2910 blocks $\operatorname{PrP}^{\mathrm{C}}$ conversion more effectively than BMD42-2914. Additionally, BMD42-2908- and BMD422909-treated cells produced minimal PrP $\mathrm{P}^{\text {res }}$, whereas they were unable to prevent conversion in our RT-QuIC assay. Consistent results would be ideal; however, consistency may be unnecessary, because anti-prion strategies vary according to the mechanism of action. The RT-QuIC data clearly confirmed the blocking of $\mathrm{rPrP}$ conversion; however, the ScN2a cell data are ambiguous because $\operatorname{PrP}^{\text {res }}$ amounts cannot be monitored continuously; therefore, the complete absence of $\mathrm{PrP}^{\text {res }}$ cannot be guaranteed and the mechanism of action is unknown for $\mathrm{ScN} 2 \mathrm{a}$ cell screening. We thus infer that BMD42-2908 and BMD42-2909 may exhibit their anti-prion activity via the degradation of $\operatorname{PrP}^{\text {res }}$, rather than blocking of $\operatorname{PrP}^{\mathrm{C}}$, since RT-QuIC indicated low activity.

$\operatorname{PrP}^{\text {res }}$ was dramatically reduced at 170 DPI in the brains of $\operatorname{PrP}^{\mathrm{Sc}}{ }_{-}$ infected mice treated with BMD42-2910, and this effect was sustained. Individual differences were not statistically significant; thus we could not conclude whether BMD42-29 has anti-prion activity in vivo. We attempted to identify anti-prion activity of the compounds at 70 DPI, to model the early state of the disease; however, load of $\mathrm{PrP}^{\text {res }}$ was not detectable in DMSO control group, and therefore this time-point was excluded from analyses (data not shown).
Administration of BMD42-2910 into the abdominal cavity is relatively convenient, requires a small amount of the compound, and has a higher absorption rate than oral administration because it bypasses the digestive system [45]. In our study, administration into the abdominal cavity resulted in high activity in the brain, as supported by several lines of evidence. First, the compound might be small enough to cross the $\mathrm{BBB}$ in order to directly affect $\mathrm{PrP}^{\mathrm{Sc}}$ in the brain. Second, the activity of the compound could be markedly observed in brain areas with extensive $\operatorname{PrP}^{\mathrm{Sc}}$ distribution. However, it was not easily distinguished in spleen or plasma, although the compound had suitable effects. This is likely because $\operatorname{PrP}^{\text {Sc }}$ in the spleen and plasma has relatively low infectivity and pathogenicity and is present at low concentration [46]. Therefore, high expression of $\operatorname{PrP}^{\mathrm{Sc}}$ is likely necessary to generate the observed outcomes in the brain.

It has been proposed that the hydrogen bonds from strand $\mathrm{S} 1$ and helix B may prevent conversion of $\operatorname{PrP}^{\mathrm{C}}$ to $\operatorname{PrP}^{\mathrm{Sc}}$ [47]. BMD4229 and BMD42-2910 had strong hydrogen bonds at Asn159, Gln160, Lys194 and Glu196 within $\operatorname{PrP}^{\mathrm{C}}$ and interacted with conserved $\operatorname{PrP}^{\mathrm{C}}$ hotspot residues, indicating the importance of hydrogen bonds interactions and the hydrophobic environment; this was predicted by the pharmacophore model. We found that BMD42-2904 shows partial anti-prion activity in our $\operatorname{PrP}^{\mathrm{Sc}}$-infected cell model, and also binds $\operatorname{PrP}^{\mathrm{C}}$ at Asn159 with a hydrogen bond. Although only one binding site was involved in the docking simulation, anti-prion activity was feasible. Therefore, we infer that compound binding to Asn 159 of $\operatorname{PrP}^{\mathrm{C}}$ may be effective. In a previous study, we reported that the hotspot regions in $\beta 1$ (Asn159), a2 (Val189, Tyr 192, and Lys194), and the a1 2 loop (Glu196), which are involved in the pathogenic conversion process, are obstructed by binding to the anti-prion compounds. In particular, the a1 a2 salt bridge between Arg156 and Glu196 of the misfolded $\operatorname{PrP}^{\mathrm{C}}$ returns to the $\operatorname{PrP}^{\mathrm{C}}$ state in the presence of BMD42-29 [27]; this finding is consistent with other reports [39, 47]. BMD42-2910 has hydrogen bonding interactions at Glu196, which are not absent in BMD42-29. Hence, the high anti-prion activity of BMD42-2910 may result from binding to Glu196 of $\mathrm{PrP}^{\mathrm{C}}$ in the binding mode.

Future research should first assess whether $\mathrm{PrP}^{\mathrm{Sc}}$ strains differ between cell (RML strain) and mouse (ME7 strain) models. As previously reported, prion studies often produce incompatible results, depending on which $\operatorname{PrP}^{\mathrm{Sc}}$ strain is used [48]. Therefore, other $\mathrm{PrP}^{\mathrm{Sc}}$ strains should be used in future studies, to enable generalization of BMD42-2910 activities. Second, BMD42-2910 should be tested using a more specific nonclinical trial in humanized models. For example, we plan to use $\operatorname{PrP}^{\mathrm{Sc}}$-infected human neuronal cells and humanized transgenic mice to study potential human-host effects. Third, cell signaling and cytokines should be analyzed in cells 
and in the brains of mice treated with BMD42-2910, to study the specific action of involved pathways. Finally, mutant PrPs at 159, 194 and 196 amino acid should be introduced in RT-QuIC assays in order to determine if these positions are important for their binding or inhibition.

In conclusion, we discovered compounds that inhibit the conversion of $\operatorname{PrP}^{\mathrm{C}}$ to $\operatorname{PrP}^{\text {res }}$ and validated the compounds using in vitro, and in vivo approaches. BMD42-2910, a derivative of BMD42-29, was selected based on the results of a previous study, which indicated that it reduces $\mathrm{PrP}^{\text {res }}$ generation sufficiently in mouse cells and the brain. Furthermore, the predicted binding mode docking into $\operatorname{PrP}^{\mathrm{C}}$ thereby indicated the existence of specific binding sites with hydrogen bonding. Therefore, the presently discovered inhibitor is a promising novel anti-prion compound with potential to reduce the fatality of prion diseases.

\section{ACKNOWLEDGEMENTS}

This research was supported by a research grant [2014NG52003-00] and funding from the Korea Centers for Disease Control and Prevention (4800-4838-303). RT-QuIC assay using sCJD brain homogenate and in vivo infection were conducted inside the Biosafety Level 3 facility of Korea Centers for Disease Control and Prevention (KCDC-11-3-06).

\section{REFERENCES}

1. Prusiner SB (1991) Molecular biology of prion diseases. Science 252:1515-1522.

2. Prusiner SB (1997) Prion diseases and the BSE crisis. Science 278:245-251.

3. Prusiner SB, Scott MR, DeArmond SJ, Cohen FE (1998) Prion protein biology. Cell 93:337-348.

4. Bolton DC, McKinley MP, Prusiner SB (1982) Identification of a protein that purifies with the scrapie prion. Science 218:1309-1311.

5. McKinley MP, Masiarz FR, Isaacs ST, Hearst JE, Prusiner SB (1983) Resistance of the scrapie agent to inactivation by psoralens. Photochem Photobiol 37:539-545.

6. DeArmond SJ, McKinley MP, Barry RA, Braunfeld MB, McColloch JR, Prusiner SB (1985) Identification of prion amyloid filaments in scrapie-infected brain. Cell 41:221-235.

7. Basler K, Oesch B, Scott M, Westaway D, Wälchli M, Groth DF, McKinley MP, Prusiner SB, Weissmann C (1986) Scrapie and cellular PrP isoforms are encoded by the same chromosomal gene. Cell 46:417-428.

8. Cohen FE, Prusiner SB (1998) Pathologic conformations of prion proteins. Annu Rev Biochem 67:793-819.

9. Kocisko DA, Baron GS, Rubenstein R, Chen J, Kuizon S, Caughey B (2003) New inhibitors of scrapie-associated prion protein formation in a library of 2000 drugs and natural products. J Virol 77:10288-10294.

10. Cashman NR, Caughey B (2004) Prion diseases--close to effective therapy? Nat Rev Drug Discov 3:874-884.

11. Cardinale A, Filesi I, Vetrugno V, Pocchiari M, Sy MS, Biocca S (2005) Trapping prion protein in the endoplasmic reticulum impairs PrPC maturation and prevents PrPSc accumulation. J Biol Chem 280:685-694.

12. Giles K, Olson SH, Prusiner SB (2017) Developing therapeutics for PrP prion diseases. Cold Spring Harb Perspect Med 7:a023747.

13. Teruya K, Doh-Ura K (2017) Insights from therapeutic studies for PrP prion disease. Cold Spring Harb Perspect Med 7:a024430.

14. Rossi G, Salmona M, Forloni G, Bugiani O, Tagliavini F (2003) Therapeutic approaches to prion diseases. Clin Lab Med 23:187-208.

15. Trevitt CR, Collinge J (2006) A systematic review of prion therapeutics in experimental models. Brain 129:2241-2265.

16. Dormont D (2003) Approaches to prophylaxis and therapy. Br Med Bull 66:281-292.

17. Otto M, Cepek L, Ratzka P, Doehlinger S, Boekhoff I, Wiltfang J, Irle E, Pergande G, Ellers-Lenz B, Windl O, Kretzschmar HA, Poser S, Prange H (2004) Efficacy of flupirtine on cognitive function in patients with CJD: a double-blind study. Neurology 62:714-718.

18. Nakajima M, Yamada T, Kusuhara T, Furukawa H, Takahashi M, Yamauchi A, Kataoka Y (2004) Results of quinacrine administration to patients with Creutzfeldt-Jakob disease. Dement Geriatr Cogn Disord 17:158-163.

19. Furlow TW Jr, Whitley RJ, Wilmes FJ (1982) Repeated suppression of Creutzfeldt-Jakob disease with vidarabine. Lancet 2:564-565.

20. Tsuboi Y, Doh-Ura K, Yamada T (2009) Continuous intraventricular infusion of pentosan polysulfate: clinical trial against prion diseases. Neuropathology 29:632-636.

21. Benito-León J (2004) Combined quinacrine and chlorpromazine therapy in fatal familial insomnia. Clin Neuropharmacol 27:201-203.

22. Arruda WO, Bordignon KC, Milano JB, Ramina R (2004) [Creutzfeldt-Jakob disease, Heidenhain variant: case report with MRI (DWI) findings]. Arq Neuropsiquiatr 62:347-352. Portuguese.

23. Haïk S, Marcon G, Mallet A, Tettamanti M, Welaratne A, 
Giaccone G, Azimi S, Pietrini V, Fabreguettes JR, Imperiale D, Cesaro P, Buffa C, Aucan C, Lucca U, Peckeu L, Suardi S, Tranchant C, Zerr I, Houillier C, Redaelli V, Vespignani H, Campanella A, Sellal F, Krasnianski A, Seilhean D, Heinemann U, Sedel F, Canovi M, Gobbi M, Di Fede G, Laplanche JL, Pocchiari M, Salmona M, Forloni G, Brandel JP, Tagliavini F (2014) Doxycycline in Creutzfeldt-Jakob disease: a phase 2, randomised, double-blind, placebo-controlled trial. Lancet Neurol 13:150-158.

24. Panegyres PK, Armari E (2013) Therapies for human prion diseases. Am J Neurodegener Dis 2:176-186.

25. Hyeon JW, Choi J, Kim SY, Govindaraj RG, Jam Hwang K, Lee YS, An SS, Lee MK, Joung JY, No KT, Lee J (2015) Discovery of novel anti-prion compounds using in silico and in vitro approaches. Sci Rep 5:14944.

26. Wang F, Wang X, Orrú CD, Groveman BR, Surewicz K, Abskharon R, Imamura M, Yokoyama T, Kim YS, Vander Stel KJ, Sinniah K, Priola SA, Surewicz WK, Caughey B, Ma J (2017) Self-propagating, protease-resistant, recombinant prion protein conformers with or without in vivo pathogenicity. PLoS Pathog 13:e1006491.

27. Choi J, Govindaraj RG, Hyeon JW, Lee K, Ma S, Kim SY, Lee J, No KT (2017) Structural insight into the antiprion compound inhibition mechanism of native prion folding over misfolding. Chem Biol Drug Des 89:907-917.

28. Wilham JM, Orrú CD, Bessen RA, Atarashi R, Sano K, Race B, Meade-White KD, Taubner LM, Timmes A, Caughey B (2010) Rapid end-point quantitation of prion seeding activity with sensitivity comparable to bioassays. PLoS Pathog 6:e1001217.

29. Cramm M, Schmitz M, Karch A, Zafar S, Varges D, Mitrova E, Schroeder B, Raeber A, Kuhn F, Zerr I (2015) Characteristic CSF prion seeding efficiency in humans with prion diseases. Mol Neurobiol 51:396-405.

30. Hyeon JW, Kim SY, Lee SM, Lee J, An SS, Lee MK, Lee YS (2017) Anti-prion screening for acridine, dextran, and tannic acid using real time-quaking induced conversion: a comparison with PrPSc-infected cell screening. PLoS One 12: e0170266.

31. Titlow WB, Lee CH, Ryou C (2013) Characterization of toxicological properties of L-lysine polymers in CD-1 mice. J Microbiol Biotechnol 23:1015-1022.

32. Jang CH, Lee S, Park IY, Song A, Moon C, Cho GW (2019) Memantine attenuates salicylate-induced tinnitus possibly by reducing NR2B expression in auditory cortex of rat. Exp Neurobiol 28:495-503.

33. Asuni AA, Hilton K, Siskova Z, Lunnon K, Reynolds R, Perry VH, O'Connor V (2010) Alpha-synuclein deficiency in the
C57BL/6JOlaHsd strain does not modify disease progression in the ME7-model of prion disease. Neuroscience 165:662674.

34. Hwang DH, Park HH, Shin HY, Cui Y, Kim BG (2018) Insulin-like growth factor-1 receptor dictates beneficial effects of treadmill training by regulating survival and migration of neural stem cell grafts in the injured spinal cord. Exp Neurobiol 27:489-507.

35. Simon D, Herva ME, Benitez MJ, Garrido JJ, Rojo AI, Cuadrado A, Torres JM, Wandosell F (2014) Dysfunction of the PI3K-Akt-GSK-3 pathway is a common feature in cell culture and in vivo models of prion disease. Neuropathol Appl Neurobiol 40:311-326.

36. Leidel F, Eiden M, Geissen M, Hirschberger T, Tavan P, Giese A, Kretzschmar HA, Schätzl H, Groschup MH (2014) Piperazine derivatives inhibit $\mathrm{PrP} / \mathrm{PrP}$ (res) propagation in vitro and in vivo. Biochem Biophys Res Commun 445:23-29.

37. Leidel F, Eiden M, Geissen M, Kretzschmar HA, Giese A, Hirschberger T, Tavan P, Schätzl HM, Groschup MH (2011) Diphenylpyrazole-derived compounds increase survival time of mice after prion infection. Antimicrob Agents Chemother 55:4774-4781.

38. Pagadala NS, Perez-Pineiro R, Wishart DS, Tuszynski JA (2015) In silico studies and fluorescence binding assays of potential anti-prion compounds reveal an important binding site for prion inhibition from $\operatorname{PrP}(\mathrm{C})$ to $\operatorname{Pr} \mathrm{P}(\mathrm{Sc})$. Eur J Med Chem 91:118-131.

39. Hosokawa-Muto J, Kamatari YO, Nakamura HK, Kuwata K (2009) Variety of antiprion compounds discovered through an in silico screen based on cellular-form prion protein structure: correlation between antiprion activity and binding affinity. Antimicrob Agents Chemother 53:765-771.

40. Kamatari YO, Hayano Y, Yamaguchi K, Hosokawa-Muto J, Kuwata K (2013) Characterizing antiprion compounds based on their binding properties to prion proteins: implications as medical chaperones. Protein Sci 22:22-34.

41. Touil F, Pratt S, Mutter R, Chen B (2006) Screening a library of potential prion therapeutics against cellular prion proteins and insights into their mode of biological activities by surface plasmon resonance. J Pharm Biomed Anal 40:822-832.

42. Vilette D (2008) Cell models of prion infection. Vet Res 39:10.

43. Béranger F, Mangé A, Solassol J, Lehmann S (2001) Cell culture models of transmissible spongiform encephalopathies. Biochem Biophys Res Commun 289:311-316.

44. Kang HE, Mo Y, Abd Rahim R, Lee HM, Ryou C (2017) Prion diagnosis: application of real-time quaking-induced conversion. Biomed Res Int 2017:5413936. 
45. Turner PV, Brabb T, Pekow C, Vasbinder MA (2011) Administration of substances to laboratory animals: routes of administration and factors to consider. J Am Assoc Lab Anim Sci 50:600-613.

46. Rubenstein R, Chang B (2013) Re-assessment of $\operatorname{PrP}(\mathrm{Sc})$ distribution in sporadic and variant CJD. PLoS One 8:e66352.

47. Kuwata K, Nishida N, Matsumoto T, Kamatari YO, Hosoka-
wa-Muto J, Kodama K, Nakamura HK, Kimura K, Kawasaki M, Takakura Y, Shirabe S, Takata J, Kataoka Y, Katamine S (2007) Hot spots in prion protein for pathogenic conversion. Proc Natl Acad Sci U S A 104:11921-11926.

48. Miller-Vedam L, Ghaemmaghami S (2013) Strain specificity and drug resistance in anti-prion therapy. Curr Top Med Chem 13:2397-2406. 